\title{
FWDによる舗装の構造評価および補修設計 システムの開発
}

\author{
丸山暉彦* ・阿部長門**・雑賀義夫***。 \\ 姫野賢治****
}

\begin{abstract}
本研究では, Falling Weight Deflectometer（FWD）による舗装の構造評価方法を 確立するために，既往の研究で得られたたわみ評価指標の境界值，区間分け，アスファ ルト混合物層の弾性係数の温度補正について検討を行った. 得られた研究成果に基づき, FWD による舗装の構造評価および補修設計システムを開発した.
\end{abstract}

KeyWords : NDT, FWD, elastic modulus, backcalculation, cumulative differences, asphalt temperature, pavement structure, rehabilitation

\section{1.はじめに}

現在の舗装の構造設計は，『アスファルト舗装要綱』11 に基づき半経験的な $\mathrm{CBR}-T_{A}$ 法を用いて行われている. この『アスファルト舗装要綱』が平成 4 年に改訂され, 多層弾性理論を用いた設計手法が参考として付録に取り 入れられている.これに伴い, 各種舗装構成層の弾性係 数評価方法が必要となってきた. さらに, 近年舗装の維 持修繥の重要性が増加し, 現場で短時間に舗装の健全度 を評価できる非破壊試験（Nondestructive Testing： NDT）が注目されてきた. 非破壊で構造評価を行う装 置の中で, 実際の交通荷重に類似した衝撃荷重を発生し, この時のたわみを測定するF Falling Weight Deflectometer（以下FWD と略す）が広く使われるようになっ てきている.この FWD 测定の特徴としては, 测定が 容易で，短時間に大量のデータ収集を行うことが可能な 点である.

また，FWDたわみを用いた舗装の構造評価より以下 のような判定を行うことが可能となる.

1）舗装構造同一区間の推定

2）舗装構成層の弾性係数の推定

3）破壊原因の推定

4）舗装寿命の推定

以上の推定を行うには, 的確な舗装の構造評価が不可 欠であり，現場における非破壊試験結果が重要な意味を 持っている.

舗装の構造評価あるいは補修工法の選定および補修断 面の設計をするための解析区間を定めるには，一般に埔 装構成や補修履歴もしくは路面性状等に基づき分類を

\footnotetext{
* 正会員 長岡技術科学大学教授 建設系 ( (940-21 新潟県長岡市上富岡町 1603-1)

** 正会員 長岡技術科学大学博士課程 材料工学専攻

***正会員 東亜道路工業(株) 技術研究所

***** 正会員 北海道大学助教授 工学部土木工学科
}

行っている.これらの解析区間を数学的に分割しかつ定 める方法として, AASHTO ${ }^{2)}$ では累積差法 (Cumulative Difference Value) を提案している.

たわみ性舗装の場合，アスファルトは感温性が高い材 料であるために，アスファルト混合物層の弾性係数は温 度の影響を受け広範囲の值を示す。したがって，推定し たアスファルト混合物層の弾性係数を評価する場合, 標 準温度に補正を行う必要がある。アスファルト混合物層 の弾性係数を補正するには, 測定時のアスファルト混合 物層の代表温度を把握する必要がある。 $\mathrm{AASHTO}^{3)}$ は，5 日間の平均気温と測定時の表面温度からアスファ ルト混合物層の深さ方向 3 箇所の温度を推定し, アス ファルト混合物層の平均温度を求める方法が提案されて いる.しかし, この方法では調查項目が多く, 平均温度 の推定に時間がかかるという久点を持っている．近藤 ら”は, 深さ別の温度分布測定結果から熱伝導方程式を 補正した半経験式を提案している. この方法は，月平均 気温と月代表舗装体内温度で推定するため, 推定したア スファルト混合物層の平均温度は 1 ケ月間同じ温度とな る.

そこで本論文では，解析区間の選定方法やアスファル 卜混合物層の平均温度の推定および弾性係数の温度補正 について検討を行い，FWDによる舗装の構造評価方法 をまとめた，さらに，舗装の構造評価に基づく補修工法 の選択及び補修断面の設計法を提案し，その適用例を示 した.

\section{2. 舗装の構造評価および補修設計システム}

FWD を用いた構造評価により舗装の構造設計を行う システムとして, Thompson ら ${ }^{5)}$ がILLI-PAVEを開 発している.この構造設計プログラムでは，FWDで得 られた弾性係数の他に繰返し三軸圧縮試験で得られるレ ジリエントモジュラス（Resilient Modulus）を用いて 
も構造設計が行えるようになっている.

また舗装の構造評価を行う場合，評価対象の考え方に より，FWD 測定方法や解析区間の延長等が異なる．舗 装マネジメントシステム $(\mathrm{PMS})^{6)}$ では，管理区域内の 道路網全体を管理するネットワークレベルと，ある路線 を適当な長さの単位区間として捉え, 管理するプロジェ クトレベルがある．本研究ではプロジェクトレベルにお ける舗装の構造評価およびその維持修繥を対象とする.

本研究で舗装の構造評価に用いている FWD 装置を 図一1に示す．本 FWD 装置は10 個のたわみセンサで たわみ量を測定している. 以下の説明では，たわみ量を $D$ で表し，載荷点からセンサまでの距離 $(\mathrm{mm})$ を添字 としてつける.つまり, 載荷点から $1500 \mathrm{~mm}$ 離れた位 置のたわみ量を $D_{1500}$ と呼ぶ.

FWD による舗装の構造評価および補修設計システム のフローを図一2に示す. 本フローは，以下に示す $2 つ$ のサブシステムから構成されている.

［1］FWDによる測定および構造評価

［2］構造評価に基づいた補修工法選定および補修断 面設計

本システムはパーソナルコンピュータ（PC-9801） 上で FWDによる舖装の構造評価, 補修工法の選定, 補修断面の設計を行い，自動的にたわみ及び舗装構造 データなよ゙のデータベースを作成するものである.

\section{3. 舗装の構造評価}

FWD 測定後のたわみデータの処理, 弾性係数の逆解 析，および舗装の構造評価についてのフローを図一3に 示す．本章では評価区間の分割方法，アスファルト混合 物層の弾性係数の温度補正, たわみ指標の境界值につい て述べる。

現在まで，FWD 測定で得られたたわみ量から舗装の 構造評価や補修工法を検討するための評価区間の分け方 は, 舗装構成, 補修履歴, たわみの変化等に基づき行っ ている.上記の目的のために区間設定を行う方法として， AASHTOで提案されている累積差を本研究で取り入 れ，自動分割できるようにした.

アスファルト混合物層の平均温度の推定は, FWD 測 定中に同時に計測する路面温度亡気温を用いて推定する 方法について検討した. また，この方法で得られたアス ファルト混合物層の平均温度を用いてアスファルト混合 物層の弾性係数を温度補正する方法を示す.

既往の研究》でたわみ評価指標を提案したが，本シス テムではこのたわみ評価指標に 3 段階のランクをつけ， 舗装の状態を把握できるようにした。

\section{（1）解析区間の考え方}

ある延長の舗装を評価する場合, 舗装構成や路床の支

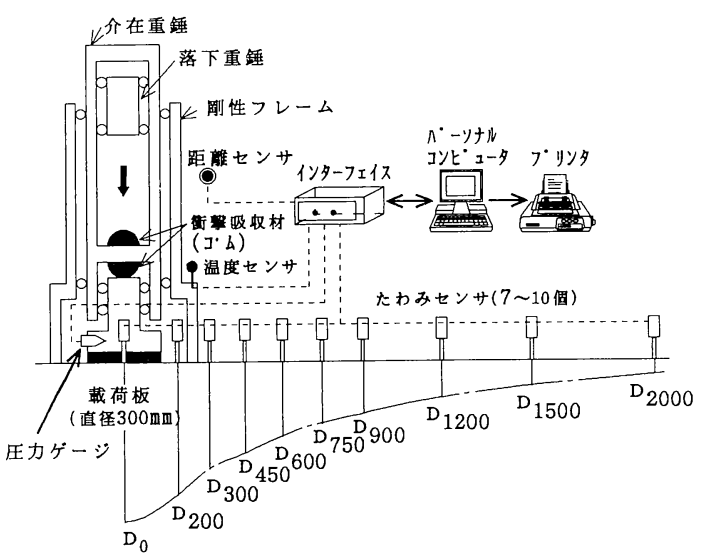

図一1 FWD 測定装置

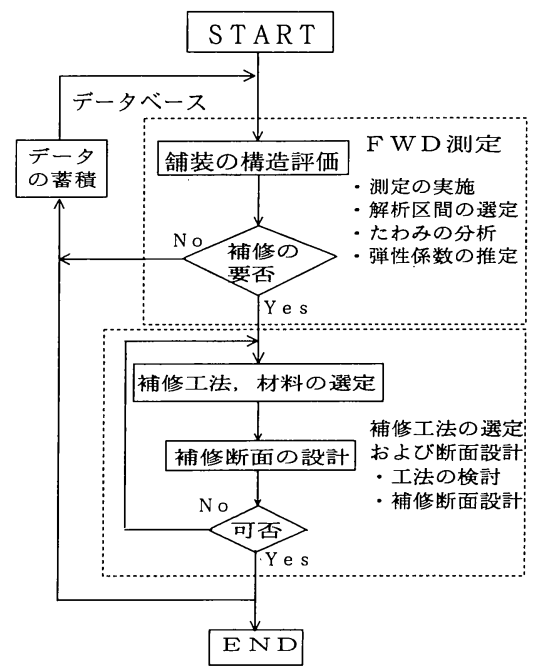

図一2 FWD による舗装構造評価および補修設計システム

持力等が均一な評価区間を選定する.この評価区間の中 で, 現状の舗装状態を表す因子がほぼ同じとみなすこと ができる区間を解析区間と呼ぶ。現況の舗装の状態を表 す因子として，たわみ，ひび割れ率，わだち掘れ量，平 坦性等があり，この因子より舗装が縦断方向にビのよう な変化をしているか捉える必要がある ${ }^{81}$. 各因子の值を 縦断方向にプロットした時, 通常かなりばらついており, ある位置で大きく変化することもある．舗装の状態を表 す因子のバラツキは, 解析区間内变動と解析区間変動に 分けられる. 解析区間の概念を図一 4 に示す.

解析区間内変動とは，ほぼ同一の舗装の状態を持って いる解析区間で，図一 4 に示されているような測定值の バラツキで発生している内部変動を示す。この変動は解 析区間の評価や設計の信頼性に影響を及ぼす．解析区間 変動は, ある評価区間の中で統計的に異なる解析区間が いくつか存在し，これを分割した時の解析区間の違いに よる変動を示す。これら解析区間の内部変動や解析区間 


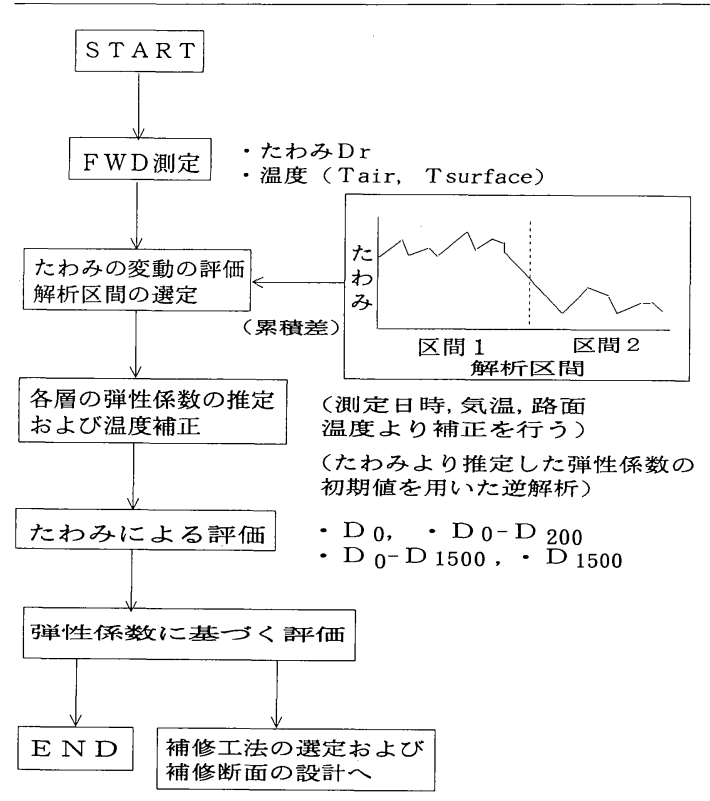

図一－FWD による舗装の構造評価

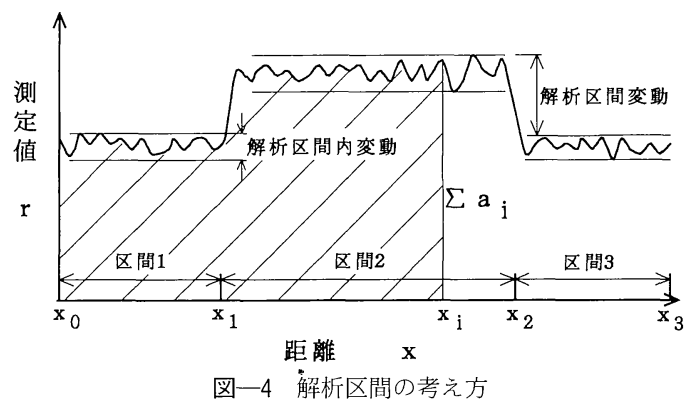

の違いを把握することは, 適切な構造評価や補修断面を 検討する際に重要となる.

a) 累積差法

FWD 測定は, 交通車両の進行方向と並行に舗装のた わみを測定する。たわみ測定は道路の縦断方向に，ある 距離 $x_{i}$ ごとに測定を行う. 載荷板中心のたわみ值を縦 断方向に連続的に結んだものが図一4である. 図中のあ る距離 $x_{i}$ における縦断線以下の累積面積 $\left(\Sigma a_{i}\right)$ と, 同 じ距離 $x_{i}$ までの平均面積 $\left(\overline{a_{i}}\right)$ の差を累積差 $Z_{x}$ という.

累積差は測定值 $r$ が連続している場合には積分をして 求めるが，FWD たわみは一般に不連続な点における測 定值であり，測定間隔も一定ではない。このような場合， 式（1），（2）より数値的に和を求めて累積差を計算す ることができる.

$$
\begin{aligned}
& Z_{x}=\sum_{i=1}^{n} a_{i}-\frac{1}{L_{p}}\left(\sum_{i=1}^{n_{t}} a_{i} \cdot \sum_{i=1}^{n} x_{i}\right) \\
& a_{i}=\frac{\left(r_{i-1}+r_{i}\right)}{2} \times x_{i}=\overline{r_{i}} \cdot x_{i} \cdot \\
& \text { ここで, } Z_{x} \text { : 累積差 }
\end{aligned}
$$

$$
\begin{aligned}
n & : n \text { 番目の測定 } \\
n_{t} & : \text { 全測定回数 } \\
a_{i} & :(i-1) \text { 番目から } i \text { 番目の面積 } \\
r_{i} & : i \text { 番目の測定値 } \\
\bar{r}_{i} & :(i-1) \text { 番目及び } i \text { 番目の測定値の平均 } \\
L_{p} & : \text { 区間の全測定長 }
\end{aligned}
$$

ある測定路線の綤積差をプロットした例を図一5に示 す.この図より, 測定值が大きく変化しているところで 実線の傾きが変化する.この実線の傾きの符号の変化点 が, 測定値に変化が生じている点の近傍となる。また, 測定間隔が一定である場合には, 式（3）で累積差を計 算することができる.

$$
Z_{x}=\sum_{i=1}^{n} a_{i}-\frac{n}{n_{t}} \sum_{i=1}^{n t} a_{i}
$$

FWD たわみに累積差による区間分けを適用すると， 図一 5 に示したように評価区間を自動的にいくつかの解 析区間に分割することが可能となる.

\section{（2）アスファルト混合物層の弾性係数の温度補正}

a) アスファルト混合物層の平均温度

現在までは既往の研究9 により, 路面温度を用いてた わみの温度補正を行っていたが, アスファルト混合物層 (以下アスコン層と略す) の平均温度を用いた温度補正 は実施していない。そこで，FWD 測定と同時に得られ る気温と路面温度から簡便にアスコン層の平均温度を推 定する方法について検討した. 温度測定用に構築した舗 装体の断面を図一6に示す. アスコン層の内部温度を測 定するために，アスコン層の層厚 $13 \mathrm{~cm}$ 中に 4 本の熱 電対を埋設した. また，気温は地上 $2 \mathrm{~m}$ の百葉箱内の 熱電対により測定した.

FWD 測定時の路面温度は接触式温度計を用いて測定 されるので, この温度計と深さ $0.5 \mathrm{~mm}$ の熱電対の温度 を比較した結果, 両者の温度を等しいとみなすことがで きた. 各埋設深さの熱電対の温度データを用いて, 積分 平均により平均温度を求めた結果, 深さ $7 \mathrm{~cm}$ の温度之 推定した平均温度はほぼ一致した。.これより, 深さ 7 $\mathrm{cm}$ の温度を平均温度とみなした。

1 日のアスファルト混合物層内の温度分布の一例を図 一7に示す. 1 日の温度分布は時刻ごとに異なっている. 同じ時刻の月別の温度分布を図一8に示す。同じ時刻の 温度分布では, 分布形状が類似している月がいくつか存 在する.この結果，年間の温度グループを 3 つに分類し た。

深さ $7 \mathrm{~cm}$ の温度を目的変数, 気温と路面温度を説明 変数とし, 年間を 3 つのグループに分割し， 1 日を 6 時 から 18 時まで 1 時間おきのグループとして, $13 \times 3=39$ 個の重回帰式を導いた。この重回帰式を式 (4) に示す.

$T_{a v e}=a T_{s u}+b T_{a i r}+c$

ここで, $T_{a v e}$ : アスコン層の平均温度 $\left({ }^{\circ} \mathrm{C}\right)$ 


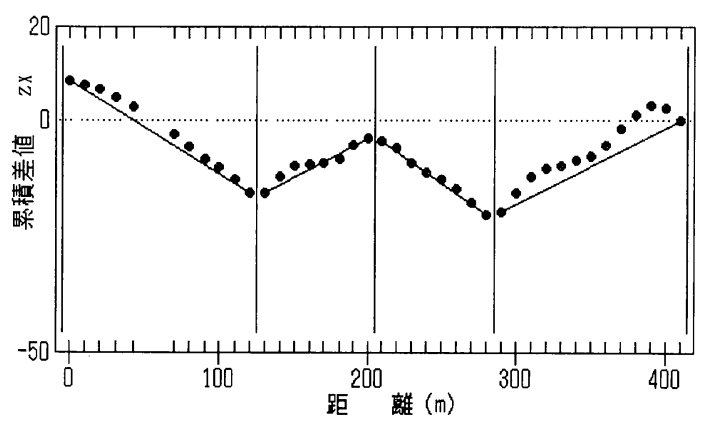

図一－累積差による区間分けの例

断面図

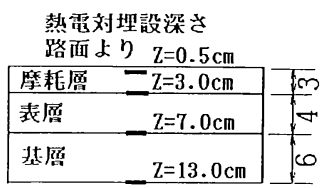

図一6 温度測定用舗装体の断面

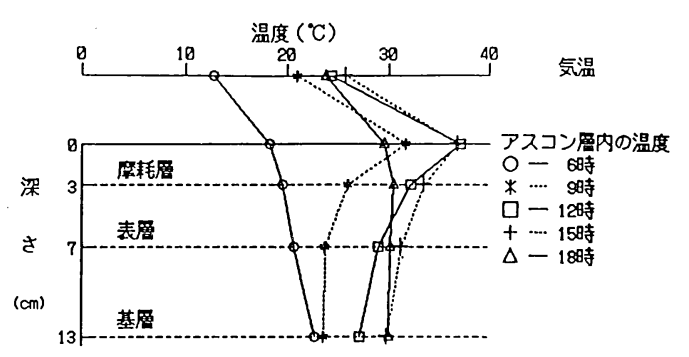

図一7 アスコン層内部の温度分布 $(91 / 5)$

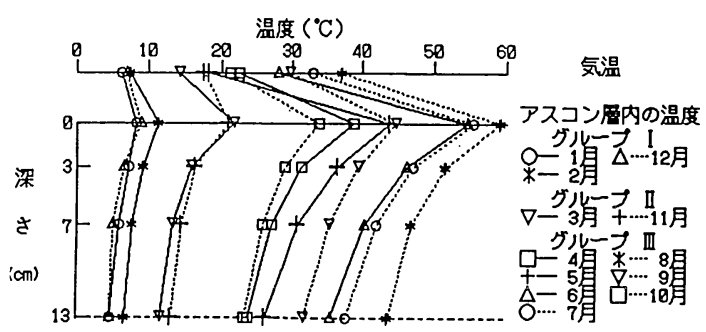

図一8 月別のアスコン層内部の温度分布（晴天-14 時）

\section{$T_{s u}$ 路面温度 $\left({ }^{\circ} \mathrm{C}\right)$}

$T_{a i r}:$ 気温 $\left({ }^{\circ} \mathrm{C}\right)$

$a, b, c$ : 推定係数

10 月のある 1 日のアスコン層の平均温度推定結果を 図一9に示す. 回帰式より推定した結果と深さ $7 \mathrm{~cm}$ の 平均温度はよく一致している。この推定式は, アスコン 層の厚さ $13 \mathrm{~cm}$ の舗装に対しての式であり, 任意厚さ のアスコン層の平均温度を推定することが必要である. 近藤らや文献 ${ }^{10)}$ では, アスコン層の厚さが異なってもア スファルト混合物中の温度分布形状は変わらないので, 熱拡散率 $k^{2}$ を一定と見なし，温度を推定しても問題は

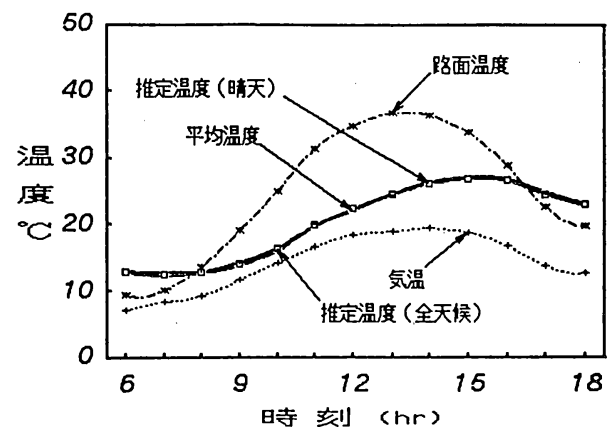

図一9 アスコン層平均温度推定結果（晴天-89 年 10 月）

ないとしている．任意厚さの平均温度を推定できるよう に, 式（4）の推定式に厚さの補正項を付加し式の拡張 について検討した。この厚さの補正項を含んだ推定式を 式 (5) に示す.

$T_{\text {ave }(z)}=\left(T_{\text {ave (13) }}\right) \alpha Z^{\beta}$

ここで, $T_{\text {ave }(z)}$ : 任意層厚のアスコン層の平均温度 $\left({ }^{\circ} \mathrm{C}\right)$

$T_{\text {ave(13) }}$ : 厚さ $13 \mathrm{~cm}$ のアスコン層の平均温 度 $\left({ }^{\circ} \mathrm{C}\right)$

$Z$ : アスコン層の厚さ $(\mathrm{cm})$

$\alpha, \beta:$ 補正係数

この平均温度推定式の精度を確認するために，つくば 市にある建設省土木研究所構内の舗装体温度デー夕 ${ }^{10} に$ 平均温度推定式を適用し, 推定温度と平均温度を比較し た。この関係を図一10 に示す。アスファルト混合物の 層厚 $20 \mathrm{~cm}$ の例であるが, この平均平方誤差は $1.5^{\circ} \mathrm{C}$ であり，実用上問題がないと考えられる.

b）アスファルト混合物層の弾性係数の温度補正 前項の結果より，アスコン層の平均温度 $\left(T_{\text {ave }(z)}\right)$ を 推定することが可能となった。 図一11に，アスコン層 の平均温度と FWD 測定結果加ら逆解析を用いて求め たアスコン層の弾性係数の関係を示す.一般に室内試験 で得られるアスコン層の平均温度と弾性係数の関係は, 高温側で弾性係数が極端に低下するので高次曲線で近似 されているが, 図一11 はFWD から推定したアスコン 層の弾性係数であり高温時に極端な弾性係数の低下はみ られない。ここでは両者の関係を一次直線で近似した。

図一11 で得られたアスコン層の平均温度と弾性係数 の回帰直線の傾きを用いて, 平均温度 $\left(T_{\text {ave(z) }}\right)$ のアス コン層の弾性係数 $\left(E_{a s(z)}\right)$ を標準温度 $20^{\circ} \mathrm{C}$ のアスコン 層の弾性係数 $\left(E_{a s(20)}\right)$ に補正する. アスコン層の弾性 係数の温度補正式を式（6）に示す。

$$
E_{a s(20)}=E_{a s(z)} \times 10^{\left[-0.0184 \times\left(20-T_{a v e(z))]} \ldots . . . .\right.\right.}
$$

ここで, $E_{a s(20)}$ : 標準温度 $20^{\circ} \mathrm{C}$ のアスコン層の弾性係 数 $(\mathrm{MPa})$ 


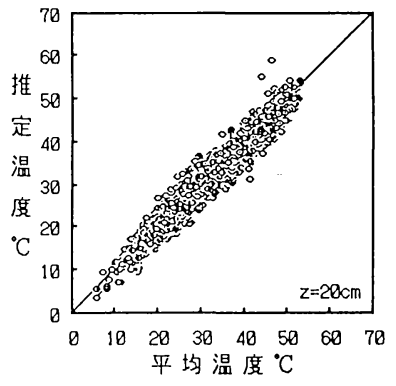

図一10 他の舗装体の温度推定結果

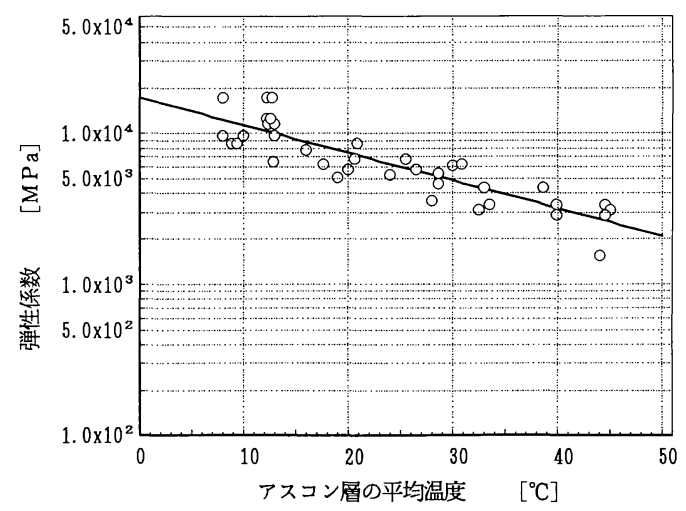

図一11 アスコン層の平均温度と弾性係数の関係

$E_{a s(z)}: T_{\text {ave(z) }}{ }^{\circ} \mathrm{C}$ のスコン層の弾性係数 ( $\mathrm{MPa}$ )

$T_{\text {ave(z) }}$ :FWD 測定時のアスコン層の平均温度 $\left({ }^{\circ} \mathrm{C}\right)$

この式を用いてアスコン層の弾性係数の温度補正を行 い, FWDによる舗装の構造評価を行う. また，アスファ ルト層の平均温度は, アスファルト混合物層が複数層の 場合においても，混合物 1 層として考える.

\section{（3）たわみ評価指標の境界値}

アスコン層の弾性係数の温度補正が可能となったの で, 標準温度 $20^{\circ} \mathrm{C}$ に補正したアスコン層の弾性係数を 用いてたわみの再計算を行い，それぞれのたわみ指標の 補正を行う.

本構造評価システムでは評価区間の舗装体の状態をた わみから簡便に判断するために, 各設計交通量ごとに既 往の研究7で得られたたわみ評価指標の境界值について 検討を行った.ここでは, 路床の文持力を含む舗装の強 度を表す $D_{0}$, 路床の支持力を表す $D_{1500}$, アスコン層の 強度を表す $D_{0}-D_{200}$, 舗装の強度を表す $D_{0}-D_{1500}$ の 4 つのたわみ評価指標について示した.

$\mathrm{A}$ 交通， B 交通，C交通，D交通の設計期間 10 年に 対応する $5 \mathrm{tf}(49 \mathrm{kN})$ 換算輪数をそれぞれ 15 万, 100 万, 700 万，3500万回之見なし，それぞれのたわみ評価指 標の $5 \mathrm{tf}(49 \mathrm{kN})$ 換算輪数におけるたわみの平均值 $\left(D_{\text {ave }}\right)$
表一1 設計交通量別のたわみ評価指標の境界值

\begin{tabular}{|c|c|c|c|c|c|c|c|c|}
\hline \multirow[t]{2}{*}{ 設計交通到 } & \multicolumn{2}{|c|}{$D_{0}(\mathrm{~mm})$} & \multicolumn{2}{|c|}{$\mathrm{D}_{1500}$ (mm) } & \multicolumn{2}{|c|}{$\mathrm{D}_{0}-\mathrm{D}_{200} \quad(\mathrm{~mm})$} & \multicolumn{2}{|c|}{$D_{0}-D_{1500}$ (man) } \\
\hline & good & poor & good & poor & good & poor & good & poor \\
\hline A交通 & $\leqq 0.71$ & $\geqq 0.89$ & \multirow{4}{*}{$\leqq 0.10$} & \multirow{4}{*}{$\geq 0.20$} & $\leqq 0.18$ & $\geqq 0.36$ & $\leqq 0.64$ & $\geq 0.70$ \\
\hline B交通 & $\leqq 0.46$ & $\geqq 0.63$ & & & $\leqq 0.07$ & $\geqq 0.15$ & $\leqq 0.45$ & $\geq 0.49$ \\
\hline C交通 & $\leqq 0.34$ & $\geqq 0.39$ & & & $\leqq 0.04$ & $\geq 0.08$ & $\leqq 0.14$ & $\geqq 0.29$ \\
\hline D交通 & $\leqq 0.25$ & $\geqq 0.32$ & & & $\leqq 0.03$ & $\geqq 0.06$ & $\leqslant 0.12$ & $\geq 0.15$ \\
\hline
\end{tabular}

を good (良い) と normal (普通) の境界值とし，たわ みの平均值＼cjkstart標準偏差 $\left(D_{\text {ave }}+\sigma\right)$ を poor (悪い) と normal (普通) の境界値とした.これを表一1に示す. 表一1の結果より, 標準温度 $20^{\circ} \mathrm{C}$ のたわみより舗装の 健全度を 3 つのランクに分類することが可能となった.

\section{4. 補修工法の選定および補修設計システム}

補修工法の選定および補修断面設計フローを図一12 に示す. 測定時のアスファルト混合物層の平均温度は前 節で示した手順で算出し, 式 $(6)$ より標準温度 $20^{\circ} \mathrm{C}$ の弾性係数に補正する.

既往の研究7)に示したようにたわみ差 $D_{0}-D_{1500}$ と $T_{A}$ の間には一意的な関係があり，たわみ差 $D_{0}-D_{1500}$ から 舗装体の相対強度を推定することが可能となっている. この値は舗装体の現在有している残存強度 $\left(T_{A 0}\right)$ に相 当するものである.

補修工法の選定には, 現状の舗装構造の力学特性を表 す $T_{A 0}$, 路床弾性係数 $E_{s g}$, および交通量区分の $3 \supset$ つ 值で特性化した補修工法選定チャートを用いて行う.

補修工法選定チャートの一例として，B交通の補修 工法選定チャートを図一16に示す. 路床弾性係数と CBRの関係は, 既往の研究11 より粘性土や砂質土で $E_{s g}\left(\mathrm{kgf} / \mathrm{cm}^{2}\right)=100 \sim 200 \mathrm{CBR}\left\{E_{s g}(\mathrm{MPa})=10 \sim 20\right.$ $\mathrm{CBR}\}$, 礫混じり土等は $E_{s g}\left(\mathrm{kgf} / \mathrm{cm}^{2}\right)=50 \sim 100 \mathrm{CBR}$ $\left\{E_{s g}(\mathrm{MPa})=5 \sim 10 \mathrm{CBR}\right\}$ である. 補修工法選定チャー 卜の作成は，粘性土や砂質土の中間值である $E_{s g}$ $\left(\mathrm{kgf} / \mathrm{cm}^{2}\right)=150 \mathrm{CBR}\left\{E_{s g}(\mathrm{MPa})=15 \mathrm{CBR}\right\}$ の関係 を用いた。図一16に示す評価区分 I とII の境界はアス ファルト舗装要綱の路床の設計 CBR 2 未満は路床改良 が必要という条件より定め, 評価区分 III と N 0 境界はア スファルト舗装要綱の設計交通量の目標 $T_{A}, \mathrm{CBR}$ の関 係から導いた。 また，評価区分 II と吕の境界は目標 $T_{A}$ $-10 \mathrm{~cm} と し た$.

\section{5. 本システムの適用例}

\section{（1）舗装の構造評価}

本章では前章までに述べた方法を用いて FWD に基 ゔく舗装の構造評価および維持設計システムの適用例を 示す。ここで用いた例は一般県道の測定例である。本路 線の設計交通量はB 交通で, 設計 CBR は 4 である. また，ひび割れ率 $20 \%$ 以上の路面状況である。評価区 間の舗装構成を図一13に示すＦWDで測定したたわ 


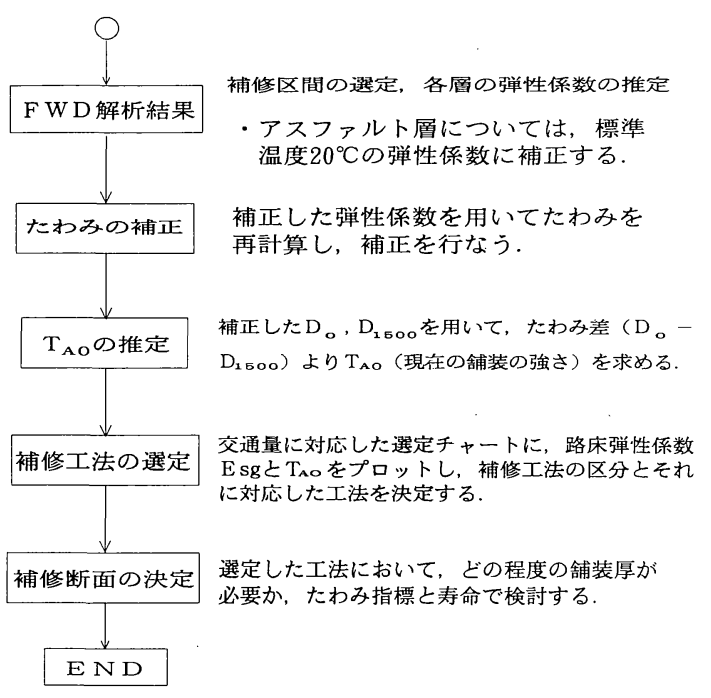

図一12 補修工法選定および補修設計のフロー図

(cm)

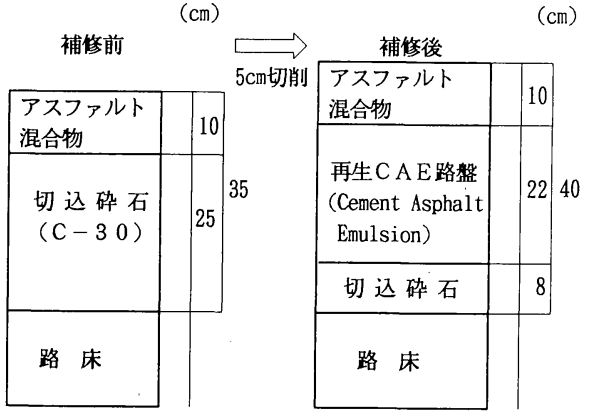

図一13 評価区間の舗装構成

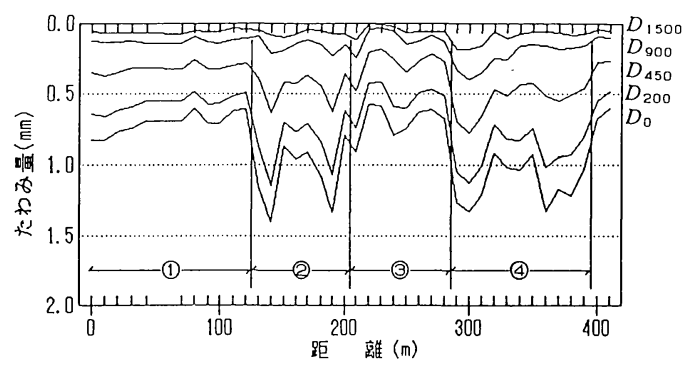

図一14 区間分けを行ったたわみ綐断図

みを縦断方向にプロットしたたわみ縦断図を図一14に 示す。図一14 は，第3 章（1）節で述べた累積差を用 いて，解析区間を定めた.

たわみの小さい区間(1)とたわみの大きい区間(2)の舗装 各層の推定弾性係数と構造評価の例を表一2に示す。ア スコン層の弾性係数は, 測定時の日時, 路面温度, 気温, アスコン層厚を式（5）に代入し，アスコン層の平均温 度を求め, 式 (5) で得られたアスコン層の平均温度之 測定時のアスコン層の弾性係数を式（6）に代入し，標 準温度 $20^{\circ} \mathrm{C}$ の弾性係数に補正した. 表中の弾性係数の
表一2 舗装各層の推定弾性係数之評価の例

\begin{tabular}{|c|c|c|c|c|c|c|c|}
\hline \multirow{3}{*}{\multicolumn{2}{|c|}{ 舖装構成 }} & \multirow{3}{*}{$\begin{array}{l}\text { 層厚 } \\
(\mathrm{mm})\end{array}$} & \multicolumn{2}{|c|}{ 区間 (1) } & \multicolumn{2}{|c|}{ 区間 (2) } & \multirow{3}{*}{ 備 考 } \\
\hline & & & 弾性係数 & ラック & 弾性係数 & 5ック & \\
\hline & & & $(\mathrm{MPa})$ & & (MPa) & & \\
\hline \multicolumn{2}{|c|}{ アスコン首 } & 100 & $6200^{\circ}$ & B & 3000 & C & \multirow[b]{3}{*}{ 評価ランク } \\
\hline \multicolumn{2}{|c|}{ 切込厒石 } & 250 & 150 & B & 85 & C & \\
\hline \multicolumn{2}{|c|}{ 路床上部 } & 500 & 65 & B & 40 & C & \\
\hline \multicolumn{2}{|c|}{ 路床下部 } & $\infty$ & 130 & A & 105 & A & A : good \\
\hline \multirow[t]{2}{*}{ たわみ } & \multicolumn{2}{|l|}{ D0 } & 0.625 & C & 0.925 & C & B: normal \\
\hline & \multicolumn{2}{|c|}{ D0-D 1500} & 0.565 & C & 0.855 & C & C:poor \\
\hline \multicolumn{2}{|c|}{$\mathrm{E}$ の評価ランク } & \multicolumn{2}{|c|}{$C:$ poor } & \multicolumn{2}{|c|}{ B : normal } & \multicolumn{2}{|r|}{ A : good } \\
\hline \multicolumn{2}{|c|}{ アスコン首 } & \multicolumn{2}{|r|}{$<3000$} & \multicolumn{2}{|c|}{$3000 \sim 6000$} & \multicolumn{2}{|r|}{$6000<$} \\
\hline \multicolumn{2}{|c|}{ 切込砕石 } & \multicolumn{2}{|r|}{$<100$} & \multicolumn{2}{|c|}{$100 \sim 300$} & \multicolumn{2}{|r|}{$300<$} \\
\hline \multicolumn{2}{|l|}{ 路 床 } & \multicolumn{2}{|r|}{$<60$} & \multicolumn{2}{|r|}{$60 \sim 100$} & \multicolumn{2}{|r|}{$100<$} \\
\hline
\end{tabular}

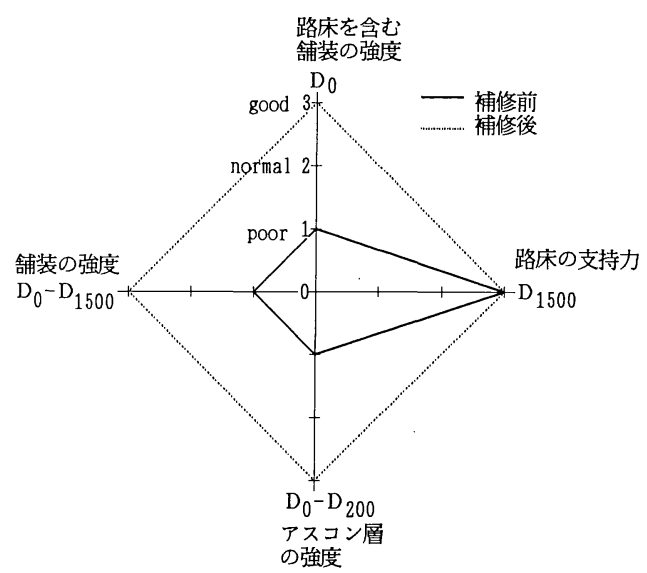

図一15 たわみ評価指標に基づくレーダチャート

ランクは，既往の研究 ${ }^{12)}$ で示した弾性係数の範囲に基づ き分類し，たわみのランクは第 3 章（３）節で示したた わみの境界値に基づき分類した. 温度補正後のたわみに 基づく評価指標のレーダチャートを図一15に示す。た わみに基づく区間(2)の舗装の評価は，路床の支持力（路 床下部）は満足しているが, 舗装（アスコン層, 路盤層) の強度が低いことがわかる。

\section{（2）補修工法の検討}

たわみの大きな区間(2)について，補修工法の検討を 行った. FWD で推定した路床弾性係数は $40 \mathrm{MPa}$ であ り, 図一16より目標 $T_{A}$ は $27 \mathrm{~cm}$ よなる. 温度補正後の $D_{0}-D_{1500}$ から求めた $T_{A 0}$ は $14 \mathrm{~cm}$ である. 本論文で提案 した補修工法選定チャートに補修前の結果を図一16に プロットする，検討区間の補修工法選定チャートの評価 ランクは【上なり,打換え工法程度の修纀が必要となる. 現行の $\mathrm{CBR}-T_{A}$ 設計法では, 設計時の $T_{A}-T_{A 0}$ が必要 オーバーレイ厚となるので, $13 \mathrm{~cm}$ のオーバーレイが必 要である。

前述の結果に基づき, 本路線ではアスコン層の全面打 換え, 再生 CAE 路盤, 打換え工法の 3 種類の補修方法 


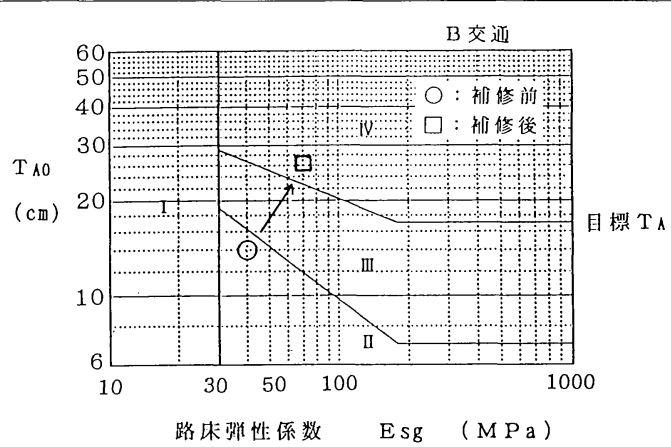

\begin{tabular}{|c|c|}
\hline 評価区分 & 補鉴工法 \\
\hline $\mathrm{I}$ & 路床改良 \\
\hline II & 打換え \\
\hline III & 部分打換え，オーバーレイ \\
\hline IV & 猞装強度满足，破損に応して対処 \\
\hline
\end{tabular}

図一16 補修工法選定チャート（補修前後）

を提案した。以降では, 再生 CAE 路盤 (Cement Asphalt Emulsion Stabilization）を用いた断面設計例 を示す.

a) $D_{0}$ のたわみの検討

再生 $\mathrm{CAE}$ 路盤工法で路盤層の厚さを変化させること により，FWD で生じるたわみがどの程度回復するか検 討した. 既往の研究 ${ }^{7,13)}$ 上り, アスコン層の弾性係数は $6000 \mathrm{MPa}$ ，再生 CAE 路盤の弾性係数は $1500 \mathrm{MPa}$ と した. その他の切込砕石, 路床の弾性係数は表一2の値 を用いた．ここでは, 再生 CAE 路盤厚を変えたときの $D_{0}$ のたわみの変化を図一17 に示す．表一1に示した B 交通の $D_{0}$ のたわみ指標より, 図一17で検討した再生 $\mathrm{CAE}$ 路盤厚は $18 \mathrm{~cm}$ 以上で good のランクに分類され る.

\section{b）舗装寿命の検討}

Asphalt Institute $(\mathrm{AI})^{1+1)}$ の提案しているアスコン層 下面の引張りひずみ, 路床上面に発生する垂直圧縮ひず みと許容載荷輪数の関係から，再生 CAE 路盤の層厚を 変化させた時に舗装の寿命がどのように変化するか調心゙ た.

前項の $D_{0}$ の計算で使用した弾性係数を用いて, 輪荷 重 $P=5 \mathrm{tf}(49 \mathrm{kN})$, 接地半径 $a=170 \mathrm{~mm}$ の条件で楜装 体に発生するひずみを求めた. 再生 $\mathrm{CAE}$ 路盤厚と路床 上面に発生する垂直圧縮ひずみから求めた許容載荷輪数 の関係を図一18に示す.

設計年数 10 年間における $B$ 交通の許容載荷輪数を 100 万回とすると, 再生 $\mathrm{CAE}$ 路盤の層厚 $22 \mathrm{~cm}$ 以上で この条件を満たす。 $D_{0}$ のたわみ指標と舖装寿命の条件 を満たす再生 $\mathrm{CAE}$ 路盤厚は $22 \mathrm{~cm}$ となり, 切込砕石層 は $8 \mathrm{~cm}$ 残る.この結果，提案した補修の舗装構成を図 -13に示す.

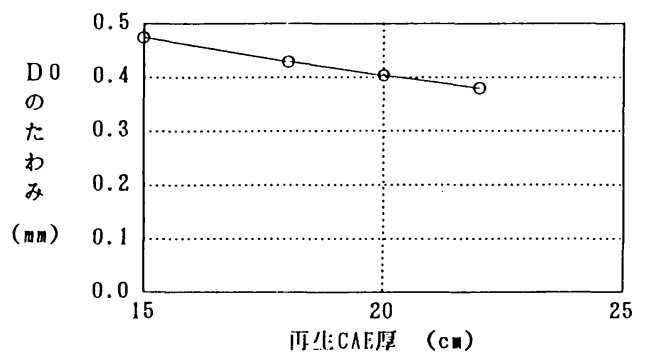

図一17 再生 $\mathrm{CAE}$ 路盤厚の変化による $D_{0}$ の変化

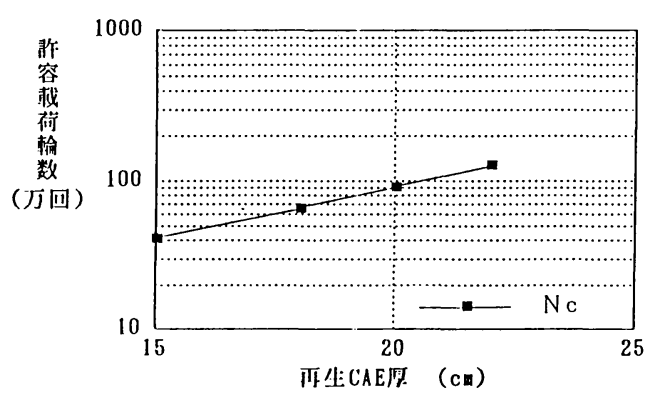

図一18 再生 CAE 路盤厚の変化による許容載荷輪数の変化

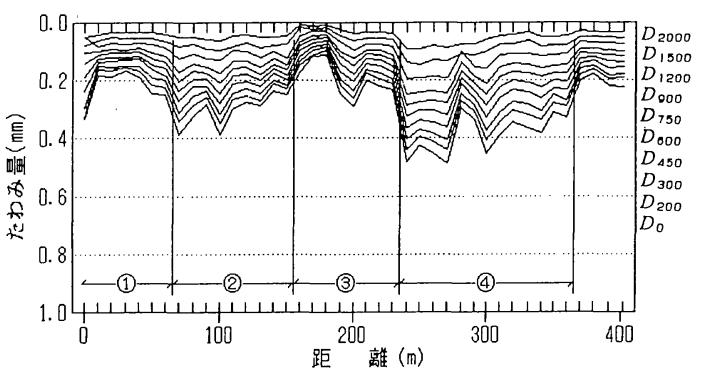

図一19補修後のたわみ縦断図

\section{（３）補修前後の比較}

適用例で示した本路線の修繥は, 再生 CAE 路盤を用 いた図一13 の補修断面で行った。補修1 ケ月後に測定 したたわみ縦断図を図一19に示す，補修前のたわみ縦 断図（図一14）と比較すると, 縦断図形状は類似してい るが，補修後のたわみが明らかに小さい。

補修後の $T_{A 0}$ を図一16の補修工法選定チャートにプ ロットし, 補修前と比較した. 補修により $T_{A 0}$ (残存 $T_{A}$ ) が $14 \mathrm{~cm}$ から $27 \mathrm{~cm}$ に回復し, 舗装が強固になり路床 上面に発生する圧縮応力・圧縮ひずみが減少し見かけの 路床弾性係数が上昇している. 本論文で提案した補修工 法選定チャートの評価区分も II からIVに上昇した。

\section{6. ま と め}

本研究の結論をまとめると以下のようになる.

1）解析区間を数学的に分割する累積差を適用し，たわ みに基づく解析区間を設定した。

2） FWD 測定中に得られる測定日時, 気温, 路面温度 
より，アスファルト混合物層の平均温度を推定する方法 を提案した.

3）測定時の平均温度におけるアスファルト混合物層の 弾性係数を標準温度の弾性係数に補正する式を提案し た.この結果, 温度に関係なくアスファルト混合物層を 一様に評価できるようになった。

4）補正したたわみより $T_{A 0}$ (残存 $T_{A}$ ) を推定し, 補 修工法選定チャートを提案した。

5）現在までに確立された研究成果や本研究で得られた 結果に基づき, 舗装の構造評価および補修設計システム を開発した。

本研究で提案した補修方法による設計例を一つだけ示 したが，他にも多数の設計事例があり，いずれも合理的 な補修断面となっている，本システムを実際の舗装にお ける補修に適用することが可能である.

\section{謝辞}

本研究は, 長岡技術科学大学技術開発センター研究プ ロジェクトの研究成果である. 研究検討会においてご協 力頂いたプロジェクトメンバーの方々に深甚なる謝意を 表する.また，デー夕整理など数多くのご協力を頂いた 長岡技術科学大学卒業生三宅克也氏 (現銭高組), およ びザイナル・アビデン氏（現マレーシア）に対し，ここ に厚く感謝の意を表する.

\section{参 考 文 献}

1）日本道路協会：アスファルト舗装要綱，Dec. 1992.

2) American Association of State Highway and Transportation Officials : AASHTO GUIDE FOR DESIGN OF
PAVEMENT STRUCTURES 1986, pp. III -17 III -22, 1986.

3) American Association of State Highway and Transportation Officials : AASHTO GUIDE FOR DESIGN OF PAVEMENT STRUCTURES 1986, Appendix L, pp.L-1 $\sim$ L-3, 1986

4）近藤佳宏・三浦裕二：アスファルト舗装体内温度の推定 に関する研究, 土木学会論文集, No. 250, pp. 123 132, 1976. 6.

5) Thompson, M. R. : ILLI-PAVE Based NDT Analysis Procedures, ASTM STP 1026, pp.487 501, 1989.

6) Hass, R. and Hudson, W.R. : Pavement Management Systems, McGRAWHILL, 1978.

7）阿部長門・丸山暉彦・姫野賢治・林正則：たわみ評価指 標に基づく舗装の構造評価, 土木学会論文集, No. 460, V-18，pp. 41 48，1993. 2 .

8）雑賀義夫：FWDによるたわみ測定の実際，アスファル ト, Vol.35, No.175, pp. 21 27, 1993.5.

9）原田尚幸ほか：FWD たわみの温度補正, 上木学会第 44 回年次学術講演会, V-21, pp. 96 97, 1989.

10）姫野賢治・渡辺隆・勝呂太：アスファルト舗装の内部温 度の推定に関する研究，土木学会論文集，No. 366, V-4, pp. 123 132, 1986. 2.

11）丸山睴彦ほか：FWDによる舗装診断システム，舖装， Vol.23, No.11, pp.16〜20, 1988.

12）三宅克哉ほか：路盤層及び安定処理層の弾性係数, 土木 学会第 45 回年次学術講演会, V-36, pp. 98 99, 1990.

13）雑賀義夫ほか：FWD による再生 CAE 路盤の弾性係数の 評価, 土木学会第 47 回年次学術講演会, V-15, pp. 62 〜63, 1992.

14) The Asphalt Institute : Research and Development of The Asphalt Institute's Thickness Design Manual (MS-1), pp.8 $\sim 11,1982.8$

(1993.6.11 受付)

\section{DEVELOPMENT OF STRUCTURAL EVALUATION AND REHABILITATION DESIGN SYSTEM FOR PAVEMENT USING FWD}

Teruhiko MARUYAMA, Nagato ABE, Yoshio SAIKA and Kenji HIMENO

To establish structure evaluation using Falling Weight Deflectometer (FWD), the results obtained in the past study were examined in this report ; the deflection indices, section division and temperature correction for asphalt mixture's elastic modulus. On the basis of these factors, the structural evaluation and rehabilitation design system was developed. 